\title{
The Use of Serial Image Media to Improve The Ability to Retell The Contents of Fairy Tales to Third Grade Students of SDN Malabar 01
}

\author{
Nene Rokaesih \\ SD Negeri Malabar 01 \\ dirgayusuf160617@gmail.com
}

\section{Article History}

accepted $14 / 11 / 2020$

approved $21 / 11 / 2020$

published 26/11/2020

\begin{abstract}
The study was entitled "The use of serial image media to improve the ability to retell storytelling content to third grade students of SDN Malabar 01 in the academic year 2020/2021".Aimed at knowing the increase in student interest and learning achievement in Indonesian language learning material Picture Series in class III SDN Malabar 01, Wanareja District. The object of the research was the third grade students of SDN Malabar 01, Wanareja sub-district, Cilacap district, with a total of 19 students. The procedure for implementing learning improvement with classroom action research is divided into three cycles. This research is focused on problems related to student interest and achievement through Thinkpair and share methods. Data obtained using observation, and test. The criteria for the success of this study can be seen from the increased interest and achievement of student learning outcomes from cycle I to cycle II and cycle II to cycle III.
\end{abstract}

Keywords: interest, learning, Think pair and share

\begin{abstract}
Abstrak
Penelitian berjudul "Penggunaan Media Gambar Seri untuk Meningkatkan kemampuan Menceritakan Kembali Isi Dongeng pada Siswa Kelas III SDN Malabar 01 Tahun Pelajaran 2020/2021". Bertujuan mengetahui peningkatan minat dan prestasi belajar siswa pada pembelajaran Bahasa Indonesia materi Gambar Seri di kelas III SDN Malabar 01 Kecamatan Wanareja. Objek penelitian adalah siswa kelas III SDN Malabar 01 kecamatan Wanareja kabupaten Cilacap dengan jumlah siswa sebanyak 19 siswa. Prosedur pelaksanaan perbaikan pembelajaran dengan penelitian tindakan kelas yang terbagi dalam tiga siklus. Penelitian ini difokuskan pada permasalahan yang berkaitan dengan minat dan prestasi belajar siswa melalui metode Think pair dan share. Data diperoleh mengunakan obeservasi, dan test. Keriteria keberhasilan penelitian ini dilihat dari peningkatan minat dan prestasi hasil belajar siswa dari siklus I ke siklus II, dan siklus II ke siklus III.
\end{abstract}

Kata kunci: Minat, belajar, Think pair and share

Social, Humanities, and Education Studies (SHEs): Conference Series https://jurnal.uns.ac.id/shes

p-ISSN 2620-9284

e-ISSN 2620-9292 


\section{PENDAHULUAN}

Kurikulum saat ini pada jenjang Sekolah Dasar adalah kurikulum 2013. Tujuan kurikulum 2013 adalah mempersiapkan manusia Indonesia agar memiliki kemampuan hidup sebagai pribadi dan warga Negara yang beriman, produktif, kreatif, inovatif, dan afektif serta mampu berkontribusi pada kehidupan bermasyarakat, berbangsa,bernegara, dan peradaban dunia. kurikulum 2013 yang berbasis karakter dan kompetensi yang mewajibkan anak untuk aktif dalam pembelajaran identifikasi masalah. karena yang kita gunakan saat ini adalah kurikulum 2013 yang berbasis karakter ini karena krisis moral yang dihadapi bangsa kita ini, korupsi, narkoba, dll yang dapat merusak bangsa kita ini, yang dampaknya luar biasa maka dari itu kita seorang pendidik digunakan untuk merubah hal itu. Menurut Undang-undang Nomor 20 Tahun 2003 tentang Sistem Pendidikan Nasional Pasal 1 butir 19, kurikulum adalah seperangkat rencana dan pengaturan mengenai tujuan, isi, dan bahan pelajaran serta cara yang digunakan sebagai pedoman penyelenggaraan kegiatan pembelajaran untuk mencapai tujuan pendidikan tertentu. Namun saat ini dunia dikejutkan dengan mewabahnya suatu penyakit yang disebabkan oleh sebuah virus yang bernama corona atau dikenal dengan istilah covid-19 (Corona Virus Diseases-19). Rumitnya penanganan wabah ini membuat para pemimpin dunia menerapkan kebijakan yang super ketat untuk memutuskan mata rantai penyebaran covid-19. Ratusan ribu manusia terpapar virus ini diseluruh dunia, bahkan puluhan ribu menjadi korban meninggal. Penularan yang sangat cepat dan sulitnya mendeteksi orang yang terpapar karena masa inkubasi covid-19 kurang lebih dua minggu menjadi penyebab banyaknya korban berjatuhan. Rumitnya penanganan wabah ini membuat para pemimpin

dunia menerapkan kebijakan yang super ketat untuk memutuskan mata rantai penyebaran covid-19. Social distancing menjadi pilihan berat bagi setiap negara dalam menerapkan kebijakan untuk pencegahan penyebaran covid-19, karena kebijakan ini berdampak negatif terhadap segala aspek kehidupan. Tak terkecuali bidang pendidikan ikut juga terdampak kebijakan ini. Keputusan pemerintah yang mendadak dengan meliburkan atau memindahkan proses pembelajaran dari sekolah/madrasah menjadi di rumah, membuat kelimpungan banyak pihak. Peralihan cara pembelajaran ini memaksa berbagai pihak untuk mengikuti alur yang sekiranya bisa ditempuh agar pembelajaran tetap dapat berlangsung, dan yang menjadi pilihan adalah pemanfaatan teknologi sebagai media pembelajaran daring.

Oleh karena itu bagaimana kita sebagai pendidik agar dapat menggunakan media pembelajaran yang digunakan untuk anak SD yang disesuaikan dengan materi dan tingkat pendidikan yang dihadapi. Media pembelajaran mengenai pelajaran anak SD biasanya lebih bersifat menyenangkan. Pada pembelajaran kelas rendah khususnya kelas tiga kemampuan guru untuk membawa siswa agar dapat mengikuti pembelajaran sangatlah penting. Khususnya dalam hal cerita dongeng Namun satu sisi Guru kurang mampu membangkitkan suasana pembelajaran yang menarik sehingga siswa mudah merasa bosan, Guru kurang mampu menggunakan media yang sesuai dan disisi lain siswa sulit menceritakan kembali isi dongeng tersebut.

Berdasarkan uraian diatas bagaimana seorang pendidik dapat meningkatkan kemampuan menceritakan kembali isi dongeng pada siswa kelas tiga melalui gambar seri. Berlatar belakang hal tersebut peneliti tertarik untuk meneliti dengan Judul "PENGGUNAAN MEDIA GAMBAR SERI UNTUK MENINGKATKAN KEMAMPUAN MENCERITAKAN KEMBALI ISI DONGENG PADA SISWA KELAS 3 SDN MALABAR 01 TAHUN PELAJARAN 2020 / 2021. Berdasarkan latar belakang masalah yang telah diuraikan diatas, maka peneliti dapat merumuskan masalah sebagai berikut :Bagaimana cara meningkatkan kemampuan menceritakan kembali isi dongeng menggunakan gambar seri pada siswa kelas 3 SDN Malabar 01 Tahun Pelajaran 2020 / 2021. Berdasarkan latar belakang diatas peneliti merumuskan permasalahan sebagai berikut Bagaimana cara meningkatkan kemampuan menceritakan kembali isi dongeng 
menggunakan gambar seri pada siswa kelas 3 SDN Malabar 01 Tahun Pelajaran 2020 / 2021.

\section{METODE}

Penelitian ini adalah penelitian tindakan kelas (Classroom Action Research) dengan menerapkan model Think pair dan share. Menurut Kurt Lewin dalam Kunandar (2011: 42) penelitian tindakan kelas ini terdiri dari empat tahapan dasar yaitu perencanaan (planning), pelaksanaan (acting), pengamatan (observing) dan refleksi (reflecting). Analisis penelitian ini adalah analisis deskriptif, kuantitafif, kualitatif dimana dalam penelitian ini selain penyajian hasil berupa data maupun angka peneliti juga menentukan bagaimana cara pengolahan hasil penelitian yakni dengan membuat analisisnya dengan menerapkan model Think pair dan share,. Penelitian ini dilaksanakan pada peserta didik kelas 3 SD Negeri Malabar 01 Tahun Pelajaran 2020/2021 selama tiga siklus secara daring menggunakan aplikasi Google meet . Siklus I dilaksanakan pada tanggal 16 November 2020. Siklus II dilaksanakan pada tanggal 23 November 2020. Siklus III dilaksanakan pada tanggal 4 Desember 2020. Teknik pengumpulan data yang dilakukan dengan observasi, tes, angket peserta didik, dan analisis data. Observasi meliputi observasi keterlaksanaan model Think pair dan share. Untuk hasil belajar menggunakan tes melalui Google form.

\section{HASIL DAN PEMBAHASAN}

Kondisi awal pembelajaran Bahasa Indonesia di kelas 3 di SD Negeri Malabar 01 pada materi Dongeng cenderung bersifat informatif atau transfer ilmu pengetahuan dari guru ke siswa sehingga siswa kurang berminat terhadap pembelajaran akibatnya hasil belajar rata-rata yang belum mencapai KKM. Hal ini tampak pada nilai rata-rata hasil ulangan harian yang diperoleh siswa kelas 3 pada kondisi awal dengan nilai rata-rata 69 dari jumlah siswa sebanyak 19 orang dan baru 9 siswa saja yang telah tuntas KKM dengan nilai KKM 70. Penelitian tindakan kelas ini dilaksanakan dalam tiga siklus yaitu siklus I materi dongeng tentang menceritakan kembali dongeng yang telah didengar ke dalam bentuk gambar, siklus 2 materi dongeng tentang menyebutkan perbuatan baik yang telah dilakukan tokoh dongeng, dan siklus 3 materi dongeng tentang pesan yang disampaikan dalam dongeng.Setiap akhir siklus diadakan ulangan harian berupa evaluasi untuk mengetahui hasil belajar siswa

Berdasarkan observasi pembelajaran, diketahui bahwa guru masih menerapkan pembelajaran searah yang menjadikan guru lebih dominan dalam kegiatan pembelajaran. Siswa hanya sebagai objek pembelajaran dalam proses pembelajaran. Dampaknya siswa kurang minat dalam kegiatan pembelajaran sehingga hasil belajar tergolong rendah. Hasil belajar siswa sebelum dilakukan tindakan dapat dilihat dari tabel berikut.

Tabel 1. Rekapitulasi peningkatan minat belajar peserta didik dari siklus I sampai siklus III.

\begin{tabular}{cccccc}
\hline \multirow{2}{*}{ No } & \multirow{2}{*}{ Uraian } & \multicolumn{2}{c}{ Peserta didik yang } & \multicolumn{2}{c}{ Peserta didik yang } \\
& & Frekuensi & $\%$ & Frekuensi & $\%$ \\
\hline 1 & Siklus I & 10 & 53 & 9 & 47 \\
2 & Siklus II & 5 & 27 & 14 & 73 \\
3 & Siklus III & 1 & 4 & 18 & 96 \\
\hline
\end{tabular}


Berdasarkan data diatas dapat kita lihat peningkatan minat dari setiap peserta didik tiap siklus sebagian besar mengalami peningkatan. Perubahan minat dapat diuraikan sebagai berikut :

1. Peserta didik yang kurang minat sebagai berikut :

a) Pada siklus I, peserta didik yang kurang minat sebanyak 10 peserta didik dari 19 peserta didik (53\%)

b) Pada siklus II, peserta didik yang kurang minat sebanyak 5 peserta didik dari 19 peserta didik (27\%)

c) Pada siklus III, peserta didik yang kurang minat sebanyak 1 peserta didik dari 19 peserta didik ( $4 \%$ )

1. Peserta didik yang sangat minat dalam belajar

a) Pada siklus I, peserta didik yang sangat minat sebanyak 9 peserta didik dari 19 peserta didik (47\%)

b) Pada siklus II, peserta didik yang sangat minat sebanyak 14 peserta didik dari 19 peserta didik $(73 \%)$

c) Pada siklus III, peserta didik yang sangat minat sebanyak 18 peserta didik dari 19 peserta didik (96\%)

Tabel 2. Rekapitulasi peningkatan hasil belajar peserta didik dari siklus I sampai siklus III.

\begin{tabular}{cccccc}
\hline \multirow{2}{*}{ No } & \multirow{2}{*}{ Uraian } & \multicolumn{2}{c}{ Peserta didik yang } & \multicolumn{2}{c}{ Peserta didik yang } \\
& & Frekuensi & $\%$ & Frekuensi & $\%$ \\
\hline 1 & Siklus I & 10 & 53 & 9 & 47 \\
2 & Siklus II & 5 & 27 & 14 & 73 \\
3 & Siklus III & 1 & 4 & 18 & 96 \\
\hline
\end{tabular}

Berdasarkan data diatas dapat kita hasil perubahan nilai yang dicapai peserta didik dari tiap siklus sebagaian besar mengalami kenaikan.

Perubahan hasil belajar dapat diuraikan sebagai berikut :

1. Pada silkus I, peserta didik yang belum tuntas belajar sebanyak 10 peserta didik dari 19 peserta didik (53\%)

2. Pada siklus II, peserta didik yang belum tuntas belajar sebanyak 5 peserta didik dari 19 peserta didik $(27 \%)$

3. Pada siklus III, peserta didik yang belum tuntas belajar sebanyak 1 peserta didik dari 19 peserta didik ( $4 \%$ )

Peserta didik yang sudah tuntas dalam belajar :

1. Pada siklus I, peserta didik yang sudah tuntas belajar sebanyak 9 peserta didik dari 19 peserta didik (47\%)

2. Pada siklus II, peserta didik yang sudah tuntas belajar sebanyak 14 peserta didik dari 19 peserta didik $(73 \%)$

3. Pada siklus III, peserta didik yang sudah tuntas belajar sebanyak 18 peserta didik dari 19 peserta didik (96\%) 
Penelitian tindakan kelas ini dilakukan dalam tiga siklus, yang masing-masing siklus dilakukan dalam 4 tahap, yaitu perencanaan tindakan, pelaksanaan tindakan, obsevasi dan refleksi. Sebelum melaksanakan tindakan siklus I peneliti terlebih dahulu mengamati proses pembelajaran untuk mengetahui minat dan prestasi belajar siswa di kelas 3 SD Negeri Malabar 01. Siklus I dilakukan sebagai tindakan perbaikan pembelajaran dari prasiklus, siklus II dilakukan sebagai tindakan dari pembelajaran siklus I, sedangkan siklus III dilakukan sebagai tindakan dari pembelajaran siklus II . Untuk mengetahui tingkat keberhasilan penelitian dilakukan pengambilan data dengan mengunakan observasi, angket dan tes. Berdasarkan penelitian tindakan kelas siklus I, siklus II , dan siklus III menunjukan peningkatan pada minat belajar siswa. Pada kondisi awal siklus I siswa yang menunjukan minat positif hanya $47 \%$ meningkat pada siklus II menjadi $73 \%$, dan pada siklus III meningkat kembali menjadi $94 \%$. Dari hasil PTK diatas yang dilakukan melalui siklus I, II, dan III melalui metode Think pair dan share mengalami keberhasilan $94 \%$.

Bimbingan dan motivasi guru mempengaruhi terhadap peningkatan minat belajar dan hasil belajar peserta didik.Sehingga model pembeljaran think pare and share pada peserta didik SDN Malabar 01 Kecamatan Wanareja Kabupaten Cilacap dapat tercapai.

\section{SIMPULAN}

Berdasarkan pelaksanaan hasil penelitian dan pembahasan yang diperoleh dari siklus I sampai dengan siklus III dapat disimpukan bahwa :

1. Penggunaan metode Think pair dan share dapat meningkatkan minat siswa di kelas III SD Negeri Malabar 01. Hal ini terlihat dari hasil evaluasi yang dilakukan selama penelitian. Setelah dilakukan metode Think pair dan share dalam pembelajarn di kelas III SD Negeri Malabar 01 berdasarkan data-data yang diperoleh terbukti metode Think pair dan share dapat meningkatakan minat peserta didik. Pembelajaran pun terlihat lebih menarik dan menyenangkan aktifitas siswa lebih dominan dari pada guru. Siswa yang awalnya malas membaca materi menjadi suka membaca materi, hal ini berdampak positif terhadap pemahaman siswa terhadap materi.

2. Metode Think pair dan share dapat meningkatkan prestasi belajar siswa di kelas III SD Negeri Malabar 01. Hal ini dibuktikan dari hasil penelitian yang menunjukan nilai siswa yang mencapai ketuntasan pada siklus kesatu hanya ada 9 atau hanya $47 \%$ saja dengan nilai rata-rata 69 . Kemudian pada siklus kedua nilai rata-rata menjadi 78 dan siswa yang mencapai ketuntasan bertambah menjadi 1 atau $73 \%$ selanjutnya di siklus ketiga nilai rata-rata menjadi 94 dengan siswa yang mencapai ketuntasan menjadi 18 atau $94 \%$.

Agus Triyanto. 2007.Bahasa Indonesia

\section{DAFTAR PUSTAKA}

Kamisa.1997. Kamus Lengkap Bahasa Indonesia. Surabaya:

Kurt Lewin dalam Kunandar (2011:42) Penelitian Tindakan Kelas

Pengertian Belajar Menurut Ahli. (Online). http // effendi-dmth.blogspot.co.id /2012/09/

Pariwara. Abbas, Hasnindah. 2011. Meningkatkan Hasil Belajar Bahasa Indonesia Keterampilan Menulis Materi Membuat Karangan Melalui Media Gambar
Pengertian
Belajar
dan
Prestasi
Belajar
Menurut Ahli.
(Online).
http://ggugutlufichasepti.blogspot.co.id/. Diakses 27 November 2015 